\title{
Retrofitting a Name: The New RBMS Conference, Leaving the "Pre" in the Past
}

At the 2014 ALA Annual Conference in Las Vegas, the RBMS Conference Development Committee and the RBMS Executive Committee initiated a discussion on changing the name of the "RBMS Preconference" to "RBMS Conference." Later, at the 2015 ALA Midwinter Meeting in Chicago, the name change was made official via the Consent Agenda item at the RBMS Executive Committee meeting. With this new name, the Section acknowledges the expanded scale and reach of our annual event, which recently has grown to more than 400 attendees and spans three and a half days. By contrast, other ALA Preconferences typically comprise a half- to one-day event.

Little did we know, as the 2014 RBMS Preconference Program Co-Chairs, that we would be planning the last Preconference-at least in name. Prescient, maybe, that we titled our Preconference "Retrofit" and offered over 400 attendees in fabulous Las Vegas an experience to reconsider the broad metaphorical themes of space, place, and the artifact in the special collections milieu, inspired by the RBMS Preconferences and meetings of the early 1960s. Although special collections practices have changed over the last 50 years, our core issues echo the challenges faced by our predecessors. Special collections professionals today regularly confront challenges in the development of collections, the creation and use of space, and the definition of our roles within the larger contexts of institutional administration and intellectual life. Focusing on the artifact, the library/archive, and the marketplace, our Preconference honored the past by addressing ways to "retrofit" ideas concerning these spaces and places fifty years ago and how pertinent these concepts are remain today.

The Preconference theme provides a natural segue to our future Conferences coming in 2015 and beyond. Retrofit was realized through the three major plenaries, and its echoes were heard throughout the event during various programming slots (such as seminars, short papers, and the like) and during social hours that encouraged more informal discussions and networking opportunities. In fact, readers will be delighted to learn that many of these talks exist online for access in original or modified format (http://rbms.info/ conferences/2014docs/). 
With this "Retrofit" theme in mind, coupled with the name change, we thought it appropriate to reach out to some of our leaders who were a part of the transition in title. Henry Raine has held many responsibilities throughout his active membership in RBMS. Notably, he was Program Chair of the 2007 Preconference, served as RBMS Section Chair from 2010 to 2011, and currently serves as chair of the Conference Development Committee. Henry shepherded the name transition as Conference Development Committee Chair and worked with the Executive Committee to formally remove the prefix and establish the new title of "Conference." Arvid Nelsen, the current RBMS Section Chair, has also served our membership in many roles, including as 2013 Preconference Local Arrangements and 2009 Preconference Program Chair. Thus, we availed ourselves of this moment to ask these two to reflect on the recent name change vis-a-vis their own experiences of the past and visions for the future of our beloved Section.

We hope that seasoned members and Preconference attendees of yore will find affinities with much of what these two have to say. As well, we salute our new members - our future leaders - and hope that you also identify with some of their candid reminisces.

\section{As we move from the Preconference to the Conference as our annual meeting, what do you see as the significance of this name change?}

Henry: "Changing the name of the RBMS 'Preconference' to RBMS 'Conference' does several things: it recognizes its significance as a major conference in its own right, independent of the ALA Annual Conference; it allows greater flexibility in scheduling the event in time and place; it offers opportunities for partnering with other organizations to hold joint conferences; and it enhances the prestige of RBMS as the major professional organization for rare book and special collections librarians."

Arvid: "I think the name established an identity for the RBMS Conference as something that really stands on its own. People come to RBMS for the strength of its programs, the host institutions and the local attractions, and the community —even when it is not in the same city as ALA and sometimes when it is not just before the Annual Meeting. People come to RBMS not as an add-on to ALA, but as the main feature."

\section{What was your first Preconference experience like? How is it different from recent ones?}

Henry: "My first RBMS Preconference was the 35th Preconference in Miami Beach in 1994, on the theme of 'From Collector to Donor: Building Special Collections with Private Passions.' I went to the Preconference after having been involved in the business end of RBMS for several years by serving on the Bibliographic Standards Committee. It was a revelation 
to me to realize that there was a whole other dimension to RBMS, a wonderful annual gathering that provided great professional development opportunities as well as opportunities for networking with other rare book and special collections librarians... What has changed also is the diversity of the attendees, and the involvement of the booksellers who were not really a feature of the earlier preconferences. That has enhanced the experience tremendously for me."

Arvid: "My first experience was amazing - I felt like I had come home. In that respect, it did not differ from more recent conferences. It was 2003 in Toronto- the year of SARS. It was a smaller conference and I found the opportunities to meet with other new and established special collections librarians incredible, especially during wonderful receptions in amazing spaces. We've grown a lot since then but I think we've maintained that atmosphere. I remember that a few other newer librarians approached me saying that they wanted us to gather informally for a drink, so that we could get to know one another better. I believe this was the start of what has become the New Member Mixer. It's just like this community to take a good idea and find a way to make it an experience that works better over time and for more people."

\section{Considering the "Retrofit" theme for RBMS LV, what aspects of the "preconference" do you think we should retain and what aspects could be "retrofitted" and considered as we move into a conference paradigm?}

Henry: "Each program committee every year has its own ideas about how the RBMS Conference should be structured, and I think that's great, because in the past we were very much stuck in the plenary/short paper/seminar mode, with not much variation in the program format and schedule from year to year. I'm very happy to see a younger generation of RBMS members bring some really innovative thinking to the conference, not just in terms of themes and topics for discussion, but also in terms of the conference experience as a whole. It seems to get better and better every year, and I certainly enjoy it more and more each year as I reconnect with old friends and colleagues and meet new people."

Arvid: "I hope that we always maintain opportunities to get to know others and engage in personal and professional discussion in an informal setting. Over the years I've heard some criticisms to dismiss the 'wine and cheese' portions of the conference, but I find that having worked in a number of larger academic libraries one can still feel isolated being in special collections. The semi-annual opportunity to get together with people who shared my interests and passions works to recharge my batteries. I still look forward to the plenary sessions and I find having good speakers who knowledgeably address a topic a great source of information. But, I also love the innovation shown by program planning teams with smaller, nimble, dynamic programming. I want more of that - and more opportunities to hear from our new members, who I think can offer a much needed perspective on the evolution of 
expectations of special collections and our larger library environments as we move through the 21st Century."

\section{What's your long view of the RBMS Conference?}

Henry: "I see the most important role of RBMS as continuing to provide these wonderful professional development opportunities to an ever more diverse membership. I see the RBMS Conference as always changing and evolving as we develop new kinds of programming and seek to involve a greater diversity of attendees."

Arvid: "I see special collections evolving as a profession now, and I expect it will continue. Many of us represent collections that value more contemporary materials and communities often overlooked and undervalued. I see a greater interconnection in collection and use of both book and archival collections. The special collections materials of tomorrow are being published today with technologies that are sometimes difficult to align with the process with which we have shown great expertise. Adapting ourselves to new publishing models, understanding emerging preservation and access issues can be difficult. But I think that our patrons and institutions will still need what I feel our core abilities are, even in the face of new technologies and models: appreciation for authenticity, provenance, and the impact of transmission on content. I believe our programs will address how to carry our core values into a world changing demographically, economically, and technologically. And I hope that we can capitalize on that technology to expand the delivery of what I'm sure will continue to be excellent programming."

We couldn't have said it better! Retrofitting our skills and expertise honors the core of our work in special collections while also demonstrating our ability and desire to adapt in the face of advancing technology and all of the collection building, service, and preservation challenges those advancements bring. And as our annual meeting advances in its own way, we continue to learn about ourselves, the communities we serve, and the composition of our profession as we strive to engage our leaders and our new colleagues alike. Maybe the "Pre" stayed in Vegas, but the Conference lives on!

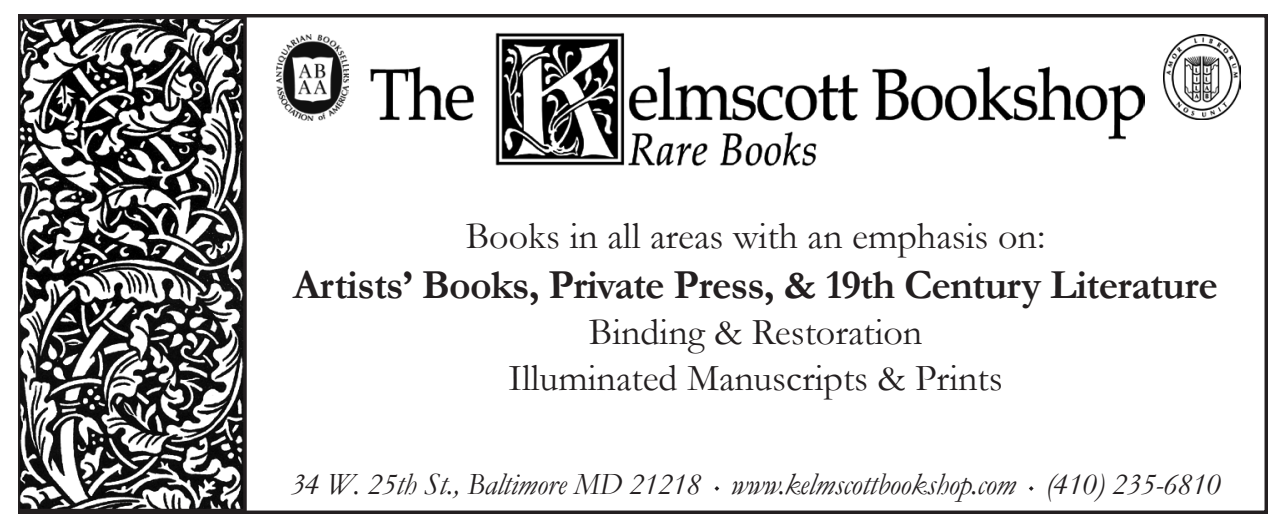

